\title{
Managing Early Childhood Care And Education: A Comparison of Government and Private Childcare Centres in Malaysia
}

Suriani Abdul Hamid, Marinah Awang, Suzyanty Mohd Shokory, Jamilah Omar \& Mazlina Che Mustafa

To Link this Article: http://dx.doi.org/10.6007/IJARBSS/v10-i11/8058

DOI:10.6007/IJARBSS/v10-i11/8058

Received: 24 September 2020, Revised: 18 October 2020, Accepted: 16 November 2020

Published Online: 30 November 2020

In-Text Citation: (Hamid et al., 2020)

To Cite this Article: Hamid, S. A., Awang, M., Shokory, S. M., Omar, J., \& Mustafa, M. C. (2020). Managing Early Childhood Care And Education: A Comparison of Government and Private Childcare Centres in Malaysia. International Journal of Academic Research in Business and Social Sciences, 10(11), 1032-1041.

Copyright: @ 2020 The Author(s)

Published by Human Resource Management Academic Research Society (www.hrmars.com) This article is published under the Creative Commons Attribution (CC BY 4.0) license. Anyone may reproduce, distribute, translate and create derivative works of this article (for both commercial and non-commercial purposes), subject to full attribution to the original publication and authors. The full terms of this license may be seen at: http://creativecommons.org/licences/by/4.0/legalcode

Vol. 10, No. 11, 2020, Pg. 1032 - 1041

Full Terms \& Conditions of access and use can be found at http://hrmars.com/index.php/pages/detail/publication-ethics 


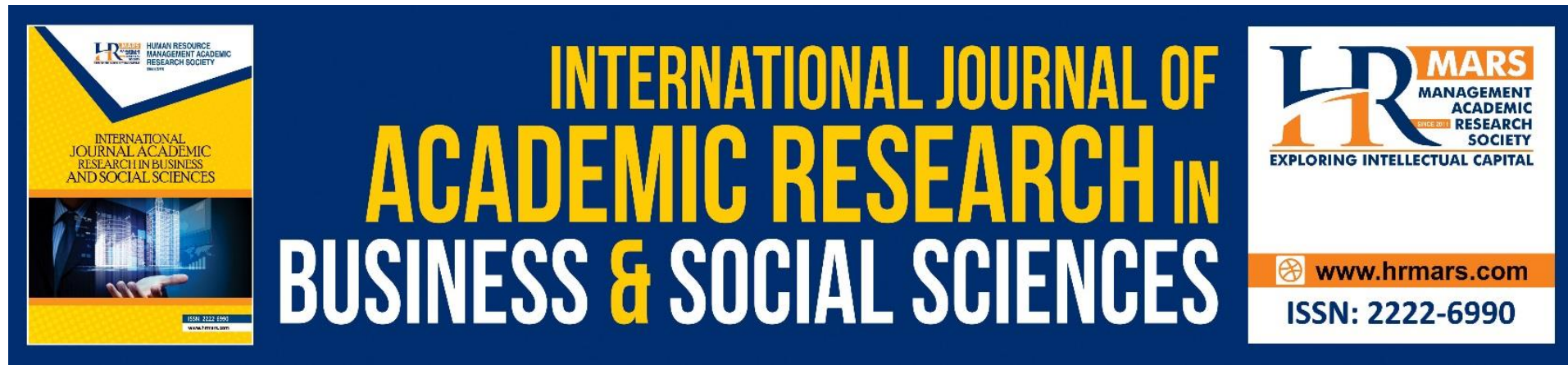

\title{
Managing Early Childhood Care And Education: A Comparison of Government and Private Childcare Centres in Malaysia
}

\author{
Suriani Abdul Hamid', Marinah Awang ${ }^{1}$, Suzyanty Mohd \\ Shokory ${ }^{1}$, Jamilah Omar² \& Mazlina Che Mustafa ${ }^{3}$ \\ ${ }^{1}$ Faculty of Management and Economics, Universiti Pendidikan Sultan Idris, ${ }^{2}$ Faculty of Art, \\ Computing and Creative Industry, Universiti Pendidikan Sultan Idris, ${ }^{3}$ Faculty of Human \\ Development, Universiti Pendidikan Sultan Idris \\ Email: suriani@fpe.upsi.edu.my,marinah@fpe.upsi.edu.my, suzyanty@fpe.upsi.edu.my, \\ jamilah@fskik.upsi.edu.my, mazlina.cm@fppm.upsi.edu.my
}

\begin{abstract}
Qualified and competent educators in early childhood centres will help to produce better quality early childhood care and education. The Malaysian government places a strong emphasis in this area for both government and private childcare centres This paper aims to understand and compare the workforce and management of early childhood care and education centres in Malaysia. A quantitative research was conducted for this study. A sample of 3,519 respondents consisting of operators, supervisors, principals, childcare providers and teachers were involved in this study using a purposive proportionate random sampling. The sample was stratified by zone i.e. northern, southern, central, east coast and west coast of peninsular Malaysia as well as East-Malaysia. The findings of the study indicated that the workforce in the government childcare centre had more staff with educational and professional qualification as well as experience. The study also found significant differences in the management of the private and government centres. This present study would benefit policymakers and the relevant authorities related to early childhood education by allowing an insight into the workforce and practices in the government and private ECCE in Malaysia.
\end{abstract} Keywords: Early Childhood Care and Education, Malaysia, Private ECCE, Government ECCE.

\section{Introduction}

Early childhood care and education (ECCE) has become a key policy for most countries to ensure high quality of early childcare and education. ECCE is one of the best investments that a country could have to promote human resource development as it could help to reduce the cost of later remedial programme (UNESCO). According to UNICEF (2020), the care and attention a child receives in the first eight years of life, particularly during the first three years, are critical and influential for the child's development. The Malaysian government places a strong emphasis on early childhood education, as the latter has become an important agenda in the Malaysian Education Development Plan 2013-2025. Given the importance of ECCE, the 
Malaysian government has also focused on increasing the quality of preschool education in the Government Transformation Programme (PEMANDU, 2015).

ECCE in Malaysia is divided into two age groups, which are between 0-4 years and 4-6 years old. The first group (0-4 years) is placed under the Ministry of Women, Family and Community Development (MWFCD), which coordinates national programmes on the growth and development of children (also known as taska). Pre-school education for the second group (46 years) is placed under three ministries/agencies, i.e. the Ministry of Education (MOE), the Ministry of Rural and Regional Development (KEMAS), and the National Unity Department (JPNIN). ECCE programmes in Malaysia are offered by two types of institutions, namely childcare centres or nurseries or taska and preschools or kindergartens or tadika. Besides public early childhood programmes established by government bodies, there are also large numbers of privately owned nurseries and preschools (Qin \& Nor, 2018).

Childcare centre or nurseries or taska has become an important service sub-sector in Malaysia (Mokhlis \& Mokhtar, 2019). The increasing rate of married women in the labour market following higher education attainment and the government's encouragement of female involvement in the labour market, caused a shift of the family institution structure. As such, this increased the demand for childcare centres. According to the Social Welfare Department Report, the number of registered nurseries increased for the past 10 years from 372 in 2009 to 4410 in 2018.

Parents in Malaysia are aware of the importance of early childhood education (Foong, Dhamotharan \& Loh, 2018). Early childhood education serves as a starting point that greatly affects a child's future. The early stages of childhood are a very important period in the process of children development involving their social, mental and emotional development. Providing good education to children at this life stage will produce a generation with the resilience to face challenges from both physical and mental aspects, as well as building intellectual power.

Taking into consideration the importance of ECCE for the country and for the child's development, good administration and management is essential. The success of an organization depends on the management's efficiency and effectiveness. In the case of ECCE, the nursery and kindergarten managers or owners are the individuals who plan, organise, lead and make decisions about how the organization should use all the available resources to achieve the ECCE goal. They are responsible for the overall operation of the centre and services provided. As cited in Hujala and Eskelinen (2013), Scrivens (2003) described the crucial tasks of ECCE leaders' daily work such as directing people (staff and parents), managing the centre (program development, planning and implementing the curriculum, monitoring children and the child/adult ratios), monitoring the program guidelines and practices (human resource management, financial management, safety and wellbeing, curriculum dissemination, inclusive practices) and maintaining the property.

Thus, the aim of this study are as follows:

- understand the workforce and the management of ECCE centres in Malaysia.

- compare the workforce and the management practices in public and private ECCE in Malaysia. 


\section{Methodology}

The data presented in this paper were part of a larger research study on Malaysian early childcare. This paper investigated childcare management in both government and private childcare centres throughout Malaysia. A purposive proportionate stratified random sampling involving 3519 operators, supervisors, principals, childcare providers and teachers from all states in Malaysia was used in this study. The sample was stratified by zone i.e. northern, southern, central, east coast and west coast of peninsular Malaysia as well as EastMalaysia.

The data were collected by questionnaire survey. The questionnaire was developed based on the review of literature from previous studies and was validated by a group of early childhood experts and practitioners. The questionnaire was pilot tested before a final version was used in the actual study. The questionnaire was divided into four sections, A, B, C and D. However, for the purpose of this paper, we would focus on Section $A$ and part of section D. Section $A$ consisted of the background information of the respondents, while Section $D$ comprised information about leadership, management and monitoring. However, this paper only focused on the management of the centre. The Cronbach alpha coefficient was 0.88 which suggested an acceptable internal consistency of the items.

The questionnaire was administered directly to operators, supervisors, principals, childcare providers, and teachers during researchers visit to the childcare centres. The respondents were briefed about the study and confidentiality of the response. Prior to the data collection exercise, consent was obtained from the Ministry of Education, and the relevant state education departments and agencies. A total of 3,519 of completed questionnaires were returned.

The data were analysed using the Statistical Package for Social Sciences (SPSS) Version 23. Descriptive statistics and t-test were employed to analyse the data. The results of the analysis are presented in the next section.

A guideline or cut-off point for the mean score was determined to interpret the result. Mean score values ranging from 1.00 to 2.33 were at low levels for each dimension or the variables studied, the mean score value obtained between 2.34 to 3.66 was at moderate stage. On the other hand, the mean score value obtained between 3.67 to 5.00 was at a high level of dimension or variable (Yusof et al., 2014)

\section{Data Analysis}

A total of 3519 respondents were involved in this study. Almost half (38\%) of the respondents were below 30 years old, followed by 31 to 40 years old (32\%). The major ethnic is Malay $(79.6 \%)$ and $82 \%$ are Muslims. The details on childcare workforce and results of the study will be presented using various sub-sections below.

\section{Positions at Childcare Centre}

The respondents in this study included operators, supervisors, principals, childcare providers, and teachers. The details of the respondents in terms of their position in the childcare centre is shown in Table 1 . As shown in Table 1, more than $50 \%$ of the respondents worked at private childcare centres. The highest percentage of the respondents were teachers in both 
government and private childcare centres. Teachers comprised $80.9 \%$ and $36.4 \%$ of the total number of respondents in government and private childcare centres respectively.

Table 1: Distribution by position at childcare centres

\begin{tabular}{|l|c|c|c|c|}
\hline Position & \multicolumn{2}{|c|}{ Government } & \multicolumn{2}{c|}{ Private } \\
\hline & Frequency & \% & Frequency & $\%$ \\
\hline Operator & 8 & 0.6 & 458 & 20.4 \\
\hline Supervisor & 50 & 3.9 & 300 & 13.4 \\
\hline Principals & 12 & 0.9 & 179 & 8 \\
\hline Childcare provider & 98 & 7.7 & 445 & 19.8 \\
\hline Teacher & 1031 & 80.9 & 816 & 36.4 \\
\hline Teacher assistant & 76 & 6 & 46 & 2 \\
\hline Total & 1275 & 100 & 2244 & 100 \\
\hline
\end{tabular}

\section{Gender}

Table 2 shows that the majority of the workforce in this study are females in both government and private childcare centre.

Table 2: Gender

\begin{tabular}{|l|c|c|c|c|}
\hline Gender & \multicolumn{2}{|c|}{ Government } & \multicolumn{2}{c|}{ Private } \\
\hline & Frequency & \% & Frequency & $\%$ \\
\hline Male & 53 & 4.2 & 83 & 3.7 \\
\hline Female & 1222 & 95.8 & 2161 & 96.3 \\
\hline
\end{tabular}

\section{Education Qualification}

The respondents' qualifications related to early childhood care and education are presented in Table 3. As shown in Table 3, a high percentage of the workforce in both government and private childcare centres in this study did not have any qualifications in Early Childhood Education. This category was the highest in private childcare centre (48.7\%), followed by Diploma holders (18.7\%) and Teaching Certificate holders (18\%). At the government childcare centres, slightly over one third (35.6\%) had a Diploma in Early Childhood Education, while $26.8 \%$ did not have any qualifications in Early Childcare Education. 
Table 3: Professional qualification holders in Early Childhood Education centres

\begin{tabular}{|c|c|c|c|c|}
\hline \multirow[t]{2}{*}{ Professional qualification } & \multicolumn{2}{|c|}{ Government } & \multicolumn{2}{|c|}{ Private } \\
\hline & Frequency & $\%$ & Frequency & $\%$ \\
\hline $\begin{array}{l}\text { PhD in Early Childhood } \\
\text { Education }\end{array}$ & 4 & 0.3 & 8 & 0.4 \\
\hline $\begin{array}{l}\text { Master's in early childhood } \\
\text { education }\end{array}$ & 11 & 0.9 & 24 & 1.1 \\
\hline $\begin{array}{l}\text { Degree in Early Childhood } \\
\text { Education }\end{array}$ & 133 & 10.4 & 89 & 4 \\
\hline $\begin{array}{l}\text { Diploma in Early Childhood } \\
\text { Education }\end{array}$ & 454 & 35.6 & 419 & 18.7 \\
\hline $\begin{array}{l}\text { Teaching Certificate in Early } \\
\text { Childhood Education }\end{array}$ & 280 & 22 & 405 & 18 \\
\hline $\begin{array}{l}\text { No qualification in Early } \\
\text { Childhood Education }\end{array}$ & 342 & 26.8 & 1092 & 48.7 \\
\hline $\begin{array}{l}\text { Did not state qualification in } \\
\text { Early Childhood Education }\end{array}$ & 51 & 4 & 207 & 9.2 \\
\hline
\end{tabular}

\section{Professional Course or Training Related to Early Childhood Education}

Table 4 shows that the attendance in courses or training programmes related to Early Childhood Education by respondents in both government and private childcare centres was low. Less than a quarter of the respondents had attended courses or training programmes.

Table 4: Professional qualification in Early Childhood Education

\begin{tabular}{|c|c|c|c|c|}
\hline \multirow[t]{2}{*}{ Professional qualification } & \multicolumn{2}{|c|}{ Government } & \multicolumn{2}{|c|}{ Private } \\
\hline & Frequency & $\%$ & Frequency & $\%$ \\
\hline $\begin{array}{l}\text { Kursus Asas Asuhan Kanak- } \\
\text { kanak (KAAK) }\end{array}$ & 439 & 34.4 & 662 & 29.5 \\
\hline $\begin{array}{l}\text { Kursus Asuhan PERMATA } \\
\text { (KAP) }\end{array}$ & 332 & 26 & 669 & 29.8 \\
\hline $\begin{array}{l}\text { Kursus Persijilan Kemahiran } \\
\text { Malaysia (SKM) Tahap } 1\end{array}$ & 16 & 1.3 & 99 & 4.4 \\
\hline $\begin{array}{l}\text { Kursus Persijilan Kemahiran } \\
\text { Malaysia (SKM) Tahap } 2\end{array}$ & 8 & 0.6 & 53 & 2.4 \\
\hline $\begin{array}{l}\text { Kursus Persijilan Kemahiran } \\
\text { Malaysia (SKM) Tahap } 3\end{array}$ & 8 & 0.6 & 113 & 5 \\
\hline $\begin{array}{l}\text { Latihan Pengajar (ToT) } \\
\text { PERMATA }\end{array}$ & 73 & 5.7 & 78 & 3.5 \\
\hline Latihan Pengajar (ToT) KAAK & 103 & 8.1 & 88 & 3.9 \\
\hline Other courses & 240 & 18.8 & 316 & 14.1 \\
\hline
\end{tabular}

\section{Working Experience}

Table 6 shows that in the government sector, $69.1 \%$ of the respondents had more than 6 years working experience and only $9.5 \%$ had less than 3 years of work experience. This indicated that the respondents were experienced in early childhood care. The findings for private 
childcare centres were different, as $37.8 \%$ of the respondents had more than 6 years of working experience, and almost $60 \%$ had 6 years of experience and below.

Table 6: Working experience

\begin{tabular}{|l|c|c|c|c|}
\hline Years & \multicolumn{2}{|c|}{ Government } & \multicolumn{2}{c|}{ Private } \\
\hline & Frequency & $\%$ & Frequency & $\%$ \\
\hline Less than 3 years & 121 & 9.5 & 775 & 34.5 \\
\hline 3-6 years & 252 & 19.8 & 568 & 25.3 \\
\hline More than 6 years & 881 & 69.1 & 849 & 37.8 \\
\hline Did not state & 21 & 1.6 & 52 & 2.3 \\
\hline
\end{tabular}

\section{Centre Management}

Table 7 shows the mean score for each item in Centre Management. The scores showed that the respondents indicated a moderate level for all the items. However, the overall scores for private childcare centres were higher than the government childcare centres.

Table 7: Descriptive analysis

\begin{tabular}{|l|l|l|l|l|l|l|}
\hline \multirow{2}{*}{ Items } & \multicolumn{2}{|c|}{ SD } & \multicolumn{2}{c|}{ Mean } & \multicolumn{2}{c|}{ Level } \\
\cline { 2 - 7 } & Govt. & Private & Govt. & Private & Govt. & Private \\
\hline $\begin{array}{l}\text { My TASKA/TADIKA has skilled } \\
\text { childcare providers/teachers in } \\
\text { handling basic first aid. }\end{array}$ & 0.565 & 0.586 & 3.04 & 3.20 & Moderate & Moderate \\
\hline $\begin{array}{l}\text { My TASKA/TADIKA has skilled } \\
\text { childcare providers/teachers to } \\
\text { handle emergency situations } \\
\text { when needed. }\end{array}$ & 0.556 & 0.571 & 3.06 & 3.22 & Moderate & Moderate \\
\hline $\begin{array}{l}\text { My TASKA/TADIKA has a } \\
\text { comprehensive, structured and } \\
\text { easily accessible records } \\
\text { management }\end{array}$ & 0.474 & 0.564 & 3.17 & 3.24 & Moderate & Moderate \\
\hline $\begin{array}{l}\text { My TASKA/TADIKA conducts } \\
\text { periodic inspections for pest } \\
\text { control. }\end{array}$ & 0.647 & 0.680 & 2.88 & 3.07 & Moderate & Moderate \\
\hline $\begin{array}{l}\text { My TASKA/TADIKA runs fire drill } \\
\text { regularly }\end{array}$ & 0.628 & 0.661 & 3.03 & 3.11 & Moderate & Moderate \\
\hline $\begin{array}{l}\text { My TASKA/TADIKA has well } \\
\text { managed and organized space }\end{array}$ & 0.525 & 0.551 & 3.22 & 3.34 & Moderate & Moderate \\
\hline $\begin{array}{l}\text { My TASKA/TADIKA manages the } \\
\text { salary of childcare } \\
\text { providers/teachers according to } \\
\text { the appropriate rate. }\end{array}$ & 0.782 & 0.612 & 3.03 & 3.31 & Moderate & Moderate \\
\hline $\begin{array}{l}\text { My TASKA/TADIKA maintains } \\
\text { outdoor play equipments in } \\
\text { good condition }\end{array}$ & 0.557 & 0.552 & 3.23 & 3.40 & Moderate & Moderate \\
\hline $\begin{array}{l}\text { My TASKA/TADIKA has a clear } \\
\text { vision and mission }\end{array}$ & 0.518 & 0.549 & 3.38 & 3.43 & Moderate & Moderate \\
\hline
\end{tabular}

An independent-sample t-test was conducted to compare the centre management scores for government and private childcare centres. There was a significant difference in scores 
for government childcare centre $(M=3.11, S D=3.62)$ and private childcare centres $(M=$ $3.25, \mathrm{SD}=3.92), \mathrm{t}()=9.623, \mathrm{p}<0.5$.

Table 8: Differences between respondents in government and private childcare centre

\begin{tabular}{llccccc}
\hline & Respondent & $\mathrm{N}$ & Mean & $\begin{array}{c}\text { Standard } \\
\text { Deviation }\end{array}$ & $\begin{array}{c}\mathrm{t} \\
\text { value }\end{array}$ & Significance \\
\hline Centre & Government & 1275 & 3.11 & 3.62 & 9.623 & 0.000 \\
management & Private & 2244 & 3.25 & 3.92 & &
\end{tabular}

\section{Discussions and Conclusion}

The Child Care Centre Act 1993 (Act 506) requires operators to ensure adequate and qualified staff; care centres are well equipped and maintained for care, control, supervision, treatment and training services. This includes providing treatment and recreational facilities. The results of this study found that nearly $80 \%$ of the respondents in government childcare centre had academic qualification in early childhood education while the percentage for private childcare centres was lower with only slightly above $50 \%$ of the respondents with qualifications in early childhood education. For staff with professional qualifications in Early Childhood Education, this recorded a low percentage in both government and private childcare centres. The level of experience varied between government and private childhood centre, where almost $70 \%$ of the respondents in government childcare centre had more than 6 years working experience. On the other hand, more than half of the respondents in private childcare centres had 6 years of experience and below. In terms of the workforce which was involved in the day- to-day operation of the childcare centre, the study results showed that the workforce in the government childcare centre had more educational and professional qualifications as well as experience. A study by Madhawa Nair, Hanafi and Yassin (2017) found that preschool teachers with higher levels of education significantly had better classroom practices than their counterparts with lower levels of education. Their study supported previous studies such as children Barnet (2016) and Rohaty (2013) which highlighted the importance of skills and professional qualifications of preschool teachers in sustaining the quality of children's care and education. Thus, policymakers should make sure that the workforce in early childhood education is well qualified.

The findings of this study also indicated significant difference in childcare centre management. Although the mean value for both the government and private childcare centre was at moderate level, the value for private childcare centre was slightly higher than the government childcare centres. This might be the fact that private childcare centres were largely driven by parental demands and expectations; as such, they were better managed. As cited in Dahari (2011), Thomson et al.(2008) stated that parents trusted private pre-schools due to their business strategy and game plan by upgrading their facilities and services to maintain their competitiveness and market niche.

Theoretically, the current study affirms the theoretical information about the condition of the ECCE workforce in Malaysia. Attention should be given as the Malaysian ECCE is growing in its importance, primarily due to the demands of the child's developmental needs and the needs of society for social, economic and political growth. In terms of practical consequences, policymakers should look more closely at this issue and take the necessary measures to 
improve the level of education and skills of the workers especially in the professional qualification in Early Childhood Education which is still lacking.

It should be acknowledged that the data and analysis of this study was subject to limitations and further studies to understand more detailed aspects of early childhood centre management should be conducted. Future studies can take into account other items that are possible to determine early childcare centre management.

\section{Acknowledgement}

This research study was supported by Ministry of Finance (MOF) through the Ministry of Education (MOE) Malaysia. We thank the National Child Development Research Centre (NCDRC), Universiti Pendidikan Sultan Idris (UPSI) as the leading university in this study in collaboration with SEGi University. This title of this study is "Development of a Comprehensive and Integrated Model of Quality Malaysian Early Childhood Care and Education (2015-0024106-04) with the sub-project is Project 3: Determining Contributing Factors of Quality ECCE" (2015-0024-106-04-3). It is funded by Ministry of Finance through Ministry of Education Malaysia. We thank all members of the research team who have contributed to this research. We also thank the steering committee, critical informants, teachers, parents and other stakeholders who participated in the study.

\section{References}

Barnet, W. S. (2016). Better teachers, better preschool: Student achievement linked to teacher qualifications. Retrieved from http://nieer.org/wpcontent/uploads/2016/08/2.pdf.

Darwish, S., Ahmed, U., \& Pahi, M. H. (2020). Innovative Work Behavior During COVID-19 for Medical Representative in the Pharmaceutical Industry: Test of a Moderation Model in Bahrain. International Journal of Pharmaceutical Research. 12(4), 19271934. doi.org/10.31838/ijpr/2020.12.04.277

Dahari, Z., \& Ya, M. S. (2011). Factors that influence parents' choice of pre-schools education in Malaysia: an exploratory study. International Journal Business and Social Science, 2 (15), 115-128.

Foong, L., Veloo, P. K., Dhamotharan, M., \& Loh, C. (2018). Private sector early childcare and education in Malaysia: Workforce readiness for further education. Kajian Malaysia, 36(1), 127-154. https://doi.org/10.21315/km2018.36.1.6

Hujala, E., \& Eskelinen, M. (2013), Leadership Tasks in Early Childhood Education, Tampere University Press.

Jabatan Kebajikan Masyarakat. (2020). Laporan Statistik Tahunan Jabatan Kebajikan Masyarakat 2009-2018.

Mokhlis, S., \& Mokhtar, N. F. (2019). Hubungan Antara Kualiti Perkhidmatan, Kepuasan Dan Kesetiaan Pelanggan Dalam Industri Taska. Journal of Business Innovation, 4(1), 13.-22.

PEMANDU. (2015). Government Transformation Programme: 2014 annual report. Retrieved from http://www.pemandu.gov.my/gtp/upload/Eng_GTP2014_AR_Full.pdf

Rohaty, M. M. (2013). Critical issues in preschool education in Malaysia. Retrieved from http://www.wseas.us/e-library/conferences/2013/CambridgeUSA/EET/EET-26.pdf.

Nair, M. S., Hanafi, Z., \& Yassin, S. (2017). Do Preschool Teachers Education Affect their Classroom Practices and Career Paths?. International Journal of Education and Practice, 5,88-94. 
Chear, S. L. S., Darkasi, S., Darini, F., Jaswir, I. S., \& Hamid, N. I. A. (2020). Pengurusan Pusat Jagaan Kanak-Kanak Berkediaman (Persendirian/NGO) di Negeri Selangor. Malaysian Journal of Social Sciences and Humanities (MJSSH), 5(8), 22-32.

UNICEF. (2020). National conference on early childhood care and education. Retrieved from http://www.unicef.org 